\title{
EFFECT OF CHRYSOMYA DOMINATION ON CALCULATING POST MORTEM INTERVAL
}

\author{
Erwin G. Kristanto ${ }^{1}$ \\ Dantje T. Sembel ${ }^{1}$ \\ Christina L. Salaki ${ }^{1}$ \\ Carla Kairupan ${ }^{1}$ \\ Hans Huijbregts ${ }^{2}$ \\ ${ }^{1}$ University of Sam Ratulangi Manado, Indonesia \\ ${ }^{2}$ Nederlands centrum voor Biodiversiteit Naturalis Leiden, Holland \\ Email: gk_erwin@yahoo.com
}

\begin{abstract}
Abstrak. Perkiraan saat kematian dihitung melalui penelitian dengan empat ekor bangkai hewan coba babi domestik pada lapangan terbuka dan area bersemak di Manado, Indonesia. Proses dekomposisi mulai dari tahap segar sampai skeletonisasi berlangsung selama 7-11 hari dengan tahap-tahap tumpang tindih, yang berbeda dengan di daerah empat musim (temperate). Chrysomya rufifacies dan Chrysomya megacepahala merupakan jenis lalat primer dominan yang ditangkap dari sekitar bangkai hewan coba dan dari hasil rearing. Simpulan: pada bangkai hewan coba yang didominasi oleh Chrysomya rufifacies dan Chrysomya megacephala, perkiraan saat kematian dengan menggunakan kedua spesies ini merupakan alat ukur terpercaya. Karakteristik perkembangan serangga amat dibutuhkan sebagai alat analitik untuk kepentingan penegakan hukum di Indonesia.
\end{abstract}

Kata kunci: Chrysomya rufifacies, Chrysomya megacephala, dominasi, post mortem interval

\begin{abstract}
Post mortem intervals (PMIs) were estimated in each of four decomposing pig carcasses located in an open field, as well as in a bushy area in Manado, Indonesia. The decomposition in Manado, proceeded from fresh to complete skeletonization, which occured within seven to eleven days, and lacked the intermediate step characteristics of decomposition as would be found in more temperate climates. Chrysomya rufifacies and Chrysomya megacepahala were the most dominant fly species collected near the carcasses, and from the rearing. Conclusion: estimation of PMIs in carcasses dominated by Chrysomya rufifacies and Chrysomya megacephala is best done by using the two spesies as measuring tools. Detailed characterization of the development of forensically important species across an array of conditions is necessary to provide adequate analytical tools for law enforcement agencies in Indonesia.
\end{abstract}

Key words: Chrysomya rufifacies, Chrysomya megacephala, domination, post mortem interval

Observations of insects present at homicide scenes and their stages of development provide forensic scientists with valuable information that assist them in estimating the time and place of death. Knowledge about necrophilous insect species and their development is very important to attain this estimation.
Numerous studies have been conducted in varied locales to calculate the development rates of various insect species under differing climatic and simulated death conditions. ${ }^{1}$ Most forensic entomological studies have been conducted in temperate and semi-tropical areas in Europe, and other developed countries, but 
few research has been conducted in tropical areas, especially in Indonesia.

The objective of this study was to characterize the infestation of the dominant necrophilious fly and its effect on other necrophilous insects in pig carcasses, in hopes of providing local law enforcement officers additional tools for estimating the minimum post mortem interval (PMI) in Indonesian homicides.

\section{MATERIALS AND METHODS}

\section{Carcasses and site description}

Observations were made of the carcasses of four similarly aged $20 \mathrm{~kg}$ domestic pigs located either in an open field or bushy area in Manado. The two study sites were situated on the northern part of Sulawesi Island. The sites were an open area and a bushy area exposed to 12 continuous hours of sunlight per day.

\section{Procedures}

The pig carcasses were placed at the sites on 27 January 2012. The first two pigs were killed with stab wounds to the heart, the third one with a blow to the back of the skull, and the fourth with a spoonful of potassium cyanide. The first, third, and fourth carcasses were placed in an open field, and the second carcass was placed in the bushes. Temperature and humidity were measured and noted twice a day. The daily mean temperature and humidity were obtained from the Badan Meteorologi Klimatologi dan Geofisika (BMKG) Stasiun Klimatologi Kayuwatu (Kayuwatu weather station) at the research site. ${ }^{2}$

Adult flies were captured from above the carcasses using a sweep net and immediately killed in a jar containing ethyl acetate. Collected flies were pinned and identified as to their species using taxonomic keys Smith $^{3}$ and Carvalho ${ }^{4}$. Maggots collected from the carcasses were labeled, killed with hot water $\left(80^{\circ} \mathrm{C}\right)$, and preserved in vials containing $70 \%$ ethyl alcohol. Maggot lengths were measured using hand-held calipers, and data entered into a spreadsheet. Ten maggots were randomly collected from throughout each maggot mass in the orifice of the head, and body of each pig carcass. These maggots were immediately placed in plastic jars containing a layer of fresh pork above a $2 \mathrm{~cm}$-soil layer and covered with a punctured plastic layer. The jars were maintained in the laboratory at $28^{0} \mathrm{C}$ for rearing. The adults emerged from rearing were identified using methods as metioned above.

\section{RESULTS}

Manado has a humid tropical forest climate. The mean temperature from January to February is $25^{\circ} \mathrm{C}$ with relative humidity ranging from $80-100 \%$. The period of this experiment was in the middle of the rainy season, when rainfall occurs almost every day. Rainfall in Manado characteristically occurs in short, intense events, two to three times a day during the rainy season.

Rectal temperatures were recorded by thermoprobes for the duration of the experiment. While rectal tissues were intact, temperatures were consistently higher in the open-field carcass. The rectal temperatures diminished from hour to hour, with the first 8- hour-temperature differences diminishing almost to none.

The most abundant fly species taken out of the sweep net from the four carcasses were Chrysomya megacephala (Figure 1) followed by Chrysomya rufifacies (Figure 2). Both Chrysomya were present from day 1 until the skeletonization phase (Table 1). Other flies collected included Hermetia illucens, the muscids, ophyra, and sarcophagids, but in very small numbers. All maggots collected from each pig carcass in the field and reared to maturity in the laboratory were $C$. megacephala, C. rufifacies, and Hermetia illucens. Carrion beetles such as Dermestes maculatus, Diamesus ocsulans, and saprinus were also collected from all carcasses in this study. Carrion beetles were observed from day 3 to the end of this study. 
Table 1. C. megacephala and C. rufifacies presence according the carcasses' time of death (in days)

\begin{tabular}{llllllllll}
\hline Ordo & Family & Genus & Species & 1 & 2 & 3 & 4 & 5 & 6 \\
\hline Diptera & Calliphoridae & Chrysomya & megacephala & + & + & + & + & + & + \\
& Calliphoridae & Chrysomya & rufifacies & + & + & + & + & + & + \\
\hline
\end{tabular}

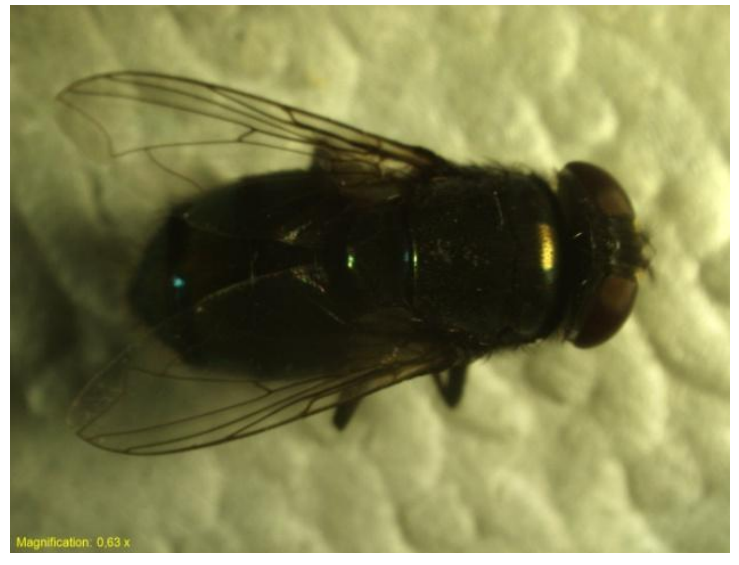

Figure 1. Chrysomya megacephala

Table 2. Development stage C. megacephala and C.rufifacies at mean temperature $25^{\circ} \mathrm{C}$ and relative humidity $80-100 \%$

\begin{tabular}{lcc}
\hline $\begin{array}{l}\text { Development } \\
\text { Stage }\end{array}$ & $\begin{array}{c}\text { C. megacephala } \\
\text { (hours) }\end{array}$ & $\begin{array}{r}\text { C.rufifacies } \\
\text { (hours) }\end{array}$ \\
\hline First instar & $18-24$ & $14-24$ \\
Second instar & $25-72$ & $25-60$ \\
Third instar & $73-120$ & $61-96$ \\
Pupae & $121-230$ & $97-242$ \\
\hline
\end{tabular}

Chrysomya maggot growth was greatest in the orifice area and in the maggot mass throughout the body. Maggot length data from all carcasses suggest that a single generation of flies infested the carcasses over the course of observation. The maggot lengths increased from time to time from the first instar to the third. The mean length of these maggots decreased from the initial stage of thrid instar until the end of third instar. Size decreases likely resulted from physiological changes in mature maggots as they ceased to feed. The developmental stages of $C$. megacephala and $C$. rufifacies were observed as shown in Table 1.

The decomposition process only took 7 to 11 days from the fresh stage to skeletonization. The five stages that could be

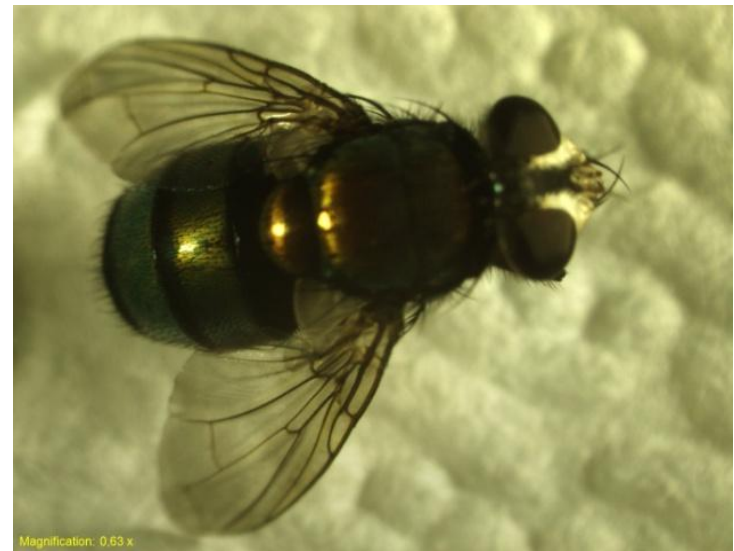

Figure 2. Chrysomya rufifacies

clearly observed in any temperate region, ${ }^{5}$ in this study were overlapping. The carcasses in both study sites underwent the same speed of decomposition. Maggot masses were found throughout the body.

\section{DISCUSSION}

Gennard (2007) divided decomposition into five general stages: fresh, bloated, activedecay, post-decay, and skeletal. Transition from one stage to the other may not be distinct since defining characteristics may overlap or vary depending on local conditions. Decomposition is generally very rapid in the tropics compared to temperate climates. Decomposition rates can vary between different locations based on microhabitat differences. ${ }^{6}$

Decomposition studies have used a variety of different carcass types and sizes. It might be expected that small carcasses would decompose more rapidly than the larger ones, but because the larger carcasses attract more flies and supported a larger number of maggots, decomposition was actually quite the same. However, extremely small carcasses such as toads, lizards, and mice have been reported to decompose very quickly. ${ }^{7}$ 
Competition among carrion breeding flies is intense, particularly among the feeding stages of larvae. The larval stages of calliphorids and sarcophagids are adapted for competitive intra- and interspecific feeding battles: larvae have short feeding periods with rapid and efficient assimilation of food, immature development occurs quickly with little moulting, digestive enzymes are modified for feeding on bacteria-infested foods, and individual larvae and feeding aggregations have high metabolic rates that generate internal heat. ${ }^{8}$ These two families are the main candidates to use in the calculation of post mortem intervals.

This study observed that in natural conditions in Manado, the sarcophagids, could not compete with Chrysomya. The Chrysomya presence excluded the sarcophagids from the host. This phenomenon happened because the development rates for the sarcophagids were lower than the Chrysomya, and the life cycle span from egg to eclosion in the Chrysomya were shorter than the the sarcophagids. ${ }^{9}$ Sarcophagid females are also viviparous, resulting lower fecundity rates compared to oviparous Chrysomya. Warm environments and high rates of decomposition favoured the Chrysomya, while the sarcophagids as a tool to calculate post mortem intervals was difficult, considering the difficulties in finding the oldest Sarcophagids larvae.

Mature $C$. rufifacies maggots that are known for their cannibalistic properties of preying on maggots of other species, seem not to prey on them because of the abundant substrate in this study. $C$. rufifacies cannot eliminate the presence of C. megacepahala and other flies. Diminishing the numbers of other species is caused by the "burning" temperature that C.rufifacies and C.megacephala maggot masses produce. C. rufifacies and C. megacephala are known to be tolerant to high substrate temperatures, and can survive in very high densities of maggots in a host. ${ }^{8}$ Using $C$. rufifacies and $C$. megacephala as tools to calculate post mortem intervals would be preferable in the case of the two species dominating the host.

Dermestes maculatus is one of few beetles that has great value in producing evidence on corpses. The dermestid females lay up to 150 eggs that hatch within about three weeks. The larval stage lasts for 5 to 15 weeks depending on the temperature and food availability. The speed of decomposition process in this study may hinder the growth of the dermestid, because within three weeks, food availability will decrease noticably. ${ }^{10}$ In using D. maculatus to calculate post mortem intervals, we must keep in mind that few adults on corpses do not represent the actual species infestation on the remains. It is likely that they come from nearby habitat and only the presence of a larvae colony represents actual infestation. Using the D. maculatus larvae colony can hinder growth, in this case which would only result in a biased PMI.

\section{CONCLUSION}

Growth of insects other than Chrysomya rufifacies and Chrysomya megacephala could be altered when the two species dominate the host. Altered growth rates may result in the bias of post mortem interval estimation. To estimate post mortem interval in carcasses that have been dominated by Chrysomya rufifacies and Chrysomya megacephala, it is best done by using the two spesies as measuring tools.

\section{ACKNOWLEDGMENTS}

This study was conducted using the facilities and equipment provided by the Plant Pests and Diseases Laboratory, Faculty of Agriculture, University of Sam Ratulangi, Manado. Ir. James Kaligis MSi assisted in providing digital recording data equipment. Reviewers at the University of Sam Ratulangi provided useful critiques of the manuscript.

\section{REFERENCES}

1. Catts EP, Goff ML. Forensic entomology in criminal investigations. Annu. Rev. 
Entomol. 1992;37:253-72.

2. BMKG North Celebes. Temperature, humidity and rain at Manado city. Badan Meteorologi, Klimatologi dan Geofisika Provinsi Sulawesi Utara, 2012; p.1-10.

3. Smith KGV. A Manual of Forensic Entomology. London: The Trustees of the British Museum, 1986; p.36-54.

4. Carvalho C, de Mello-Patiu C. Key to the adults of the most common forensic species of Diptera in South America. Revista Brasileira de Entomologia. 2008;52(3):390-406.

5. Anderson G, VanLaerhoven SL. Initial studies on insect succession on carrion in southwestern British Columbia. Journal of forensic sciences. 1996; 41(4):617-625.

6. Gennard DE. Forensic Entomology: An Introduction. London: John Wiley \&
Sons Ltd., 2007.

7. Payne JA. A summer carrion study of the baby pig Sus Scrofa Lineaus. Ecology. 1965;46:592-602.

8. Rivers DB, Thompson C, Brogan R. Physiological Trade-offs of Forming Maggot Masses by Necrophagous Flies on Vertebrate Carrion. Bulletin of Entomological Research. 2011;101: 599-611.

9. Shiravi AH, Mostafavi R, Akbarzadeh K, Oshaghi MA. 2011. Temperature requirements of some common forensically important blow and flesh flies (Diptera) under laboratory conditions. Iran J Arthropod-Borne Dis. 2011;5(1):54-62.

10. Kulsrestha PD, Satpathy K. Use of beetles in forensic entomology. Forensic Science International. $2001 ;(120): 15-17$. 